\title{
Proventricular structure in solitary bees (Hymenoptera: Apoidea)
}

\author{
José Eduardo Serrão* \\ Departamento de Biologia Geral, Universidade Federal de Viçosa, Viçosa 36570-000, MG, Brazil
}

Received 17 June 2004; accepted 21 October 2004

\begin{abstract}
Proventricular structure, analyzed by scanning electronic microscopy, is compared among 28 species of solitary bees representing four families. Observations on the shapes of proventricular folds and on hair-like cuticular projections are presented, discussed, and suggested as useful to future studies of bee systematics.
\end{abstract}

(C) 2005 Gesellschaft für Biologische Systematik. Published by Elsevier GmbH. All rights reserved.

Keywords: Insect; Morphology; Evolution; Gut; Proventriculus

\section{Introduction}

In bees, the foregut consists of the pharynx, esophagus, crop (honey sac), and proventriculus (Chapman, 1998). The proventriculus is the most specialized part of the foregut; it lies between the honey sac and the midgut (Snodgrass, 1956). It is subdivided into three parts: (1) an anterior end that protrudes into the honey sac lumen and forms the proventricular bulb, which consists of four lips leaving an $\mathrm{x}$-shaped opening; (2) a midsection or neck; and (3) a posterior cardiac valve situated within the midgut lumen (Cruz-Landim and Rodrigues, 1967; Serrão and Cruz-Landim, 1995).

As the proventriculus is ectodermic in origin, it is lined by a sclerotized cuticular intima. At the proventriculus bulb level, this cuticle is highly sclerotized, and generally many hairs arise from the upper parts of the lips to form a comb. This comb filters solid particles from the crop contents down to the midgut as results of muscular action. Bailey (1952) and Peng and Marston (1986) have described this filtering mechanism.

\footnotetext{
${ }^{*}$ Tel.: + 553138992510 ; fax: + 553138992549 .

E-mail address: jeserrao@ufv.br (J.E. Serrão).
}

Bailey (1952), Gibbs (1967), Lebrun (1985), Lebrun and Lequet (1985), and Caetano (1988) have reported anatomical variation in the insect proventriculus, which they related to the feeding habits of the insects. However, some studies have shown that insect gut morphology is not variable in relation to feeding habits (for a review see Terra and Ferreira, 1994).

The extant bees with species found in Brazil belong to five families: Colletidae, Halictidae, Andrenidae, Megachilidae and Apidae (Roig-Alsina and Michener, 1993; Alexander and Michener, 1995; Engel, 2000; Silveira et al., 2002).

Data sets for reconstructing phylogenetic trees of bees are, for the most part, based on gross morphological or behavioral characters, or on molecular data (Cameron, 1991; Sheppard and McPherson, 1991; Roig-Alsina and Michener, 1993; Alexander and Michener, 1995; Drumond et al., 2000; Engel, 2000; Costa et al., 2003). Anatomical, histological or cytological data are rarely incorporated, and the few such studies mostly pertain to other insects (Bilinski et al., 1998; Bitsch and Bitsch, 1998; Klass, 1998; Kubrakiewicz et al., 1998; Strausfeld, 1998; Buschbeck, 2000; Ehmer and Hoy, 2000; Serrão, 2000; Peixoto and Serrão, 2001). 
The purpose of the present paper is to investigate proventricular bulb morphology in solitary bees in order to contribute to future cladistic studies.

Table 1. List of taxa used in the analysis

Apidae
Apinae
Centridini
Centris (Centris) aenea Lepeletier, 1841
Centris (Hemisella) tarsata Smith, 1874
Centris (Heterocentris) analis (Fabricius, 1804)
Centris (Heterocentris) labrosa Friese, 1899
Centris (Melacentris) violacea Lepeletier, 1841
Centris (Trachina) fuscata Lepeletier, 1841
Epicharis (Epicharana) flava (Friese, 1900)
Epicharis (Epicharana) rustica (Olivier, 1879)
Epicharis (Epicharis) bicolor Smith, 1874
Epicharis (Triepicharis) analis Lepeletier, 1841
Epicharis (Triepicharis) schrottkyi Friese, 1899
Exomalopsini
Exomalopsis (Exomalopsis) auropilosa Spinola, 1853
Exomalopsis (Exomalopsis) fulvofasciata Smith, 1879

Eucerini

Melissoptila richardiae Bertoni and Schrottky, 1910

Thygater analis (Lepeletier, 1841)

Thygater palliventris (Friese, 1908)

Emphoprini

Melitoma segmentaria (Fabricius, 1804)

Ericrocidini

Mesocheira bicolor (Fabricius, 1804)

Tapinotaspidini

Arhysoceble xanthopoda Moure, 1948

Xylocopinae

Xylocopa (Neoxylocopa) frontalis (Olivier, 1879)

Xylocopa (Schonnherria) subcyanea Perez, 1901

Andrenidae

Oxaea flavescens Klug, 1807

Megachilidae

Anthidium (Anthidium) latum Schrottky, 1902

Anthidium (Anthidium) manicatum (Linnaeus, 1758)

Megachile (Holcomegachile) giraffa Schrottky, 1913

Megachile (Leptorachis) aureiventris Schrottky, 1902

Megachile (Leptorachis) paulistana Schrottky, 1902

Colletidae

Ptiloglossa sp. (Smith 1853)

Sphecidae

Psenulus sp.

Vespidae

Polybia paulista (Ihering, 1896)

Polistes versicolor (Olivier, 1791)

\section{Materials and methods}

Original observations are based upon dissections of freshly killed specimens collected in Viçosa, Minas Gerais state, Brazil.

The proventriculi were isolated from dissected guts and transferred to $4 \%$ paraformaldehyde at phosphate buffer $0.1 \mathrm{M}, \mathrm{pH}$ 7.2. The pieces were dehydrated in an ethanol series, transferred to hexamethyldisilazane (HMDS) for $5 \mathrm{~min}$, air dried (Nation, 1983), coated with gold, and analyzed under a Jeol scanning electron microscope (SEM).

Morphometric data on hair length and density were obtained from SEM micrographs, but due to low numbers of specimens per taxon, statistical analyses were not performed, except for the Spearman correlations between hair length and body size. Body size was determined from measurements of the thoracic intertegular distance (Cane, 1987).

The 28 taxa used in this study (Table 1) include representatives of Apinae (Centridini, Exomalopsini, Eucerini, Emphorini, Ericrocidini, Tapinotaspidini, and Xylocopinae), Megachilidae, Colletidae, and Andrenidae, as well as outgroup wasps (Vespidae and Sphecidae). Data for Sphecidae and Vespidae were obtained from Serrão (2000) and von Zuben and Caetano (1994).

Comparing proventriculi among solitary bees (Figs. 1-4), six characters (Appendix A: A-F) were used for phylogenetic considerations. Character polarity was determined using outgroup comparison (Watrous and Wheeler, 1981; Maddison et al., 1984; Nixon and

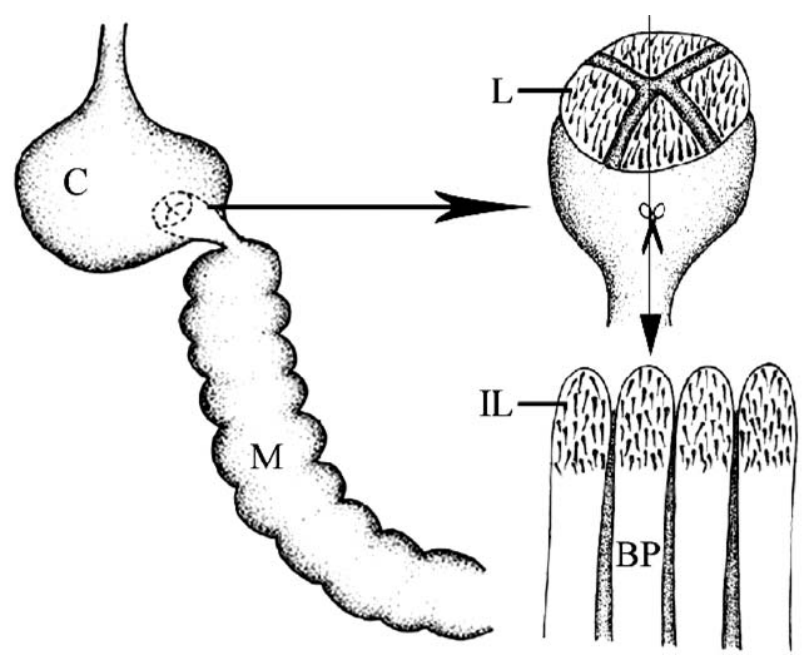

Fig. 1. Schematic drawing showing position (left) and structures (right) of the proventricular bulb. Positioned inside the crop ( $\mathrm{C} ; \mathrm{M}=$ midgut), the bulb carries four movable lips (L) lined with hair-like cuticular projections. Scissors and associated arrow indicate plane of dissection to expose internal structures (shown at bottom right), such as the basal plate (BP) and inner surfaces of the movable lips (IL). 


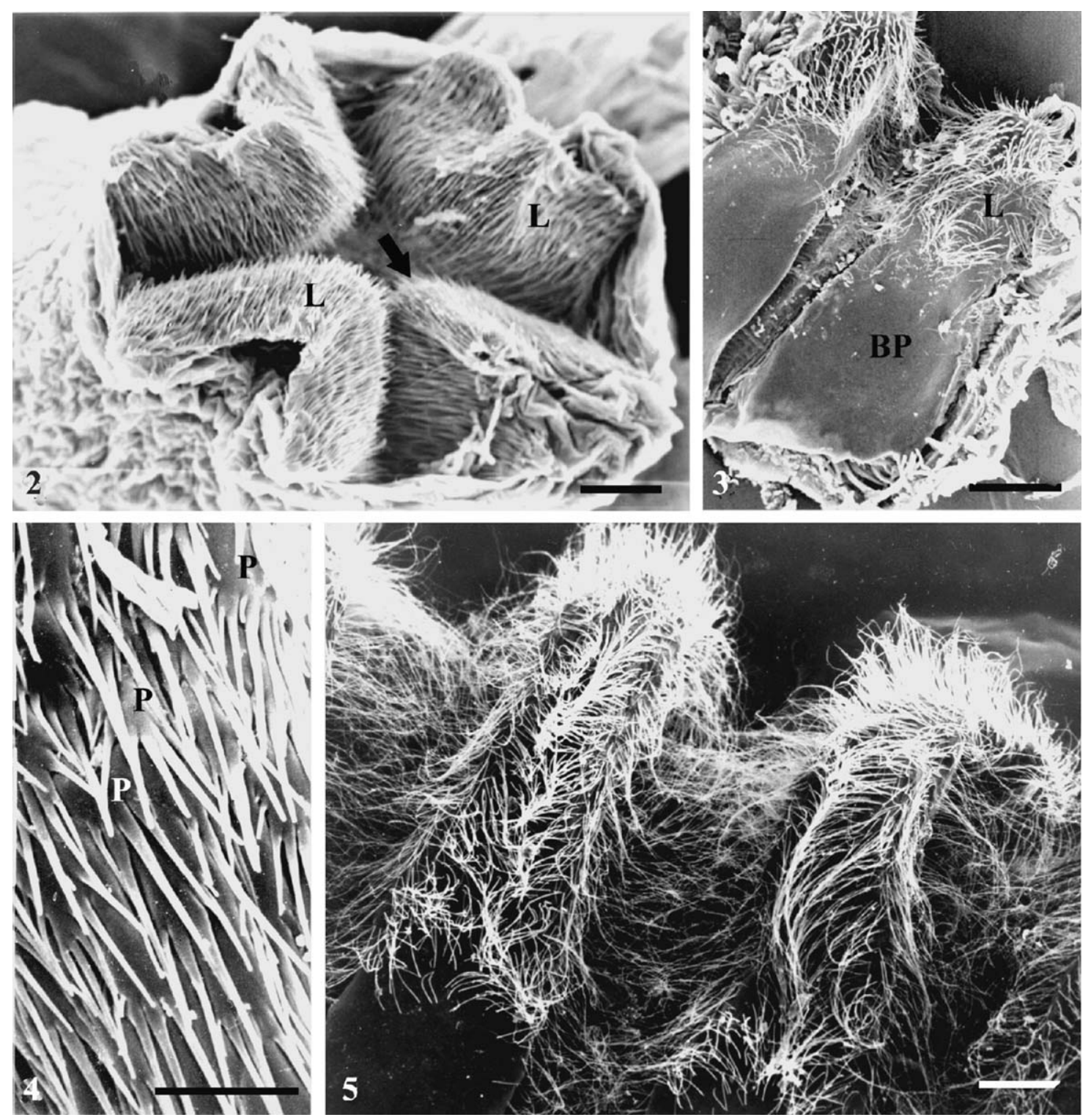

Figs. 2-5. Scanning electronic micrographs of proventriculus structures. 2. Apical view of proventricular bulb in Megachile (Leptorachis) aureiventris, showing the four movable lips (L) with hairs (arrow); scale bar $=50 \mu \mathrm{m}$. 3. Inner view of proventricular fold in Anthidium (Anthidium) manicatum (Megachilidae), showing movable lips (L) with hairs and basal plate (BP) without hairs; scale bar $=100 \mu \mathrm{m}$. 4. Proventricular hairs in Centris (Centris) aenea (Centridini), showing their arrangement in plates with spinelike projections $(\mathrm{P})$; scale bar $=10 \mu \mathrm{m}$. 5. Long, thread-shaped and densely packed proventricular hairs in Melitoma segmentaria (Emphorini); scale bar $=50 \mu \mathrm{m}$.

Carpenter, 1993). Polarity was determined by comparison with three genera, one representing Sphecidae, and two Vespidae (Table 1), the principal outgroup. Character states represented in the outgroup were considered as plesiomorphic and coded (0). Morphometric data were obtained by simple distance measures; hair densities were obtained as the number of hairs in an area of $100 \mu \mathrm{m}^{2}$ on the proventriculus. These morphometric characters show differences between individuals, and the respective ranges of such variation constituted the character states used in the analysis. Where these ranges did not overlap among taxa, the data were taken for cladistic analysis; their polarity was also based on comparison with outgroup taxa, unless values for the latter overlapped those of any ingroup taxon. For characters with two or more states, all were considered as unordered using character state optimization accelerated transformation (ACCTRAN). Cladistic analyses were performed using the computer program PAUP, version 4.0b10 (Swofford, 1998). Analysis of genera employed PAUP's star-decomposition search option. Results were illustrated by using TreeView version 16.6. 


\section{Results}

In all species studied, the proventricular bulb is located inside the crop (Fig. 1), and formed by four thick folds of the proventricular wall, the apical external surfaces of which present large numbers of hairs (Figs. 1 and 2). Each proventricular fold can be divided in two regions: an apical region forming a movable lip carrying hairs, and a basal plate without hairs, but covered by a chitinous cuticle (Figs. 1 and 3).

Within the basic morphological pattern described above, some variation can be considered among the different bee groups analyzed.

Among Apinae, Centris, Epicharis, Thygater and Mesocheira present a high density of proventricular hairs (Table 2) that form plates with 5-8 spine-like projections (Fig. 4). Melitoma, Arhysoceble and Exomalopsis have the hairs long and thread-shaped (Figs. 5 and 6), and arranged at medium density (Table 2), whereas Melissoptila has relatively sparse hairs (Table 2) that are spine-like (Fig. 7).

Xylocopa is the only genus studied in which barbed proventricular hairs were observed. The barbs are very short and arise from one side of the longer hairs only (Fig. 8). Barbed hairs were $4.34 \pm 1.52$ and $5.74 \pm 0.70 \mu \mathrm{m}$ long in $X$. frontalis and $X$. subcyanea, respectively, while long hairs were $76.77 \pm 5.75$ and $78.40 \pm 3.60 \mu \mathrm{m}$ long in $X$. frontalis and $X$. subcyanea, respectively, but at low densities (Table 2 ).

In Megachilidae, the proventricular basal plate is widened (Fig. 9), contrasting with columnar folds found in the others bees analyzed; the thread-shaped hairs are distributed at medium density (Table 2; Fig. 10).

The proventricular bulb tip in Oxaea flavescens carries hairs with a cylindrical base approx. $10 \mu \mathrm{m}$ in length, from which three longer branches arise (Fig. 12). On the inner surface of the proventriculus there are hairs of various sizes: long and thread-shaped hairs, and very short hairs scattered among the long ones (Fig. 11). Both hair types are present at low densities (Fig. 12).

Ptiloglossa sp. (Colletidae) has proventricular folds with an enlarged base and a triangular apex with a low density of spine-like cuticular projections (Figs. 13 and 14).

Morphometric data on proventriculus hair length and density are summarized in Table 2 . No correlation $(r=-0.112, P=0.66)$ between hair length and body size of the bees was found.

By applying the character states for the proventricular bulb listed in Appendix A it is possible to use parsimony analysis to construct a tree based on these proventriculi characteristics alone (Table 3 ). A consensus of the trees resulting from cladistic analysis is shown in Fig. 15. The bee clade (node 1) is supported by the shape of the proventricular fold (character A). Node 3 is supported by the combination of character states A-3, B-3, C-1,
Table 2. Morphometric data for the hair-like projections on the proventricular moving lips

\begin{tabular}{|c|c|c|c|}
\hline Species & & $\begin{array}{l}\text { Hair length } \\
(\text { mean } \pm \mathrm{sd} \\
\text { in } \mu \mathrm{m})\end{array}$ & $\begin{array}{l}\text { Hair } \\
\text { density } \\
\text { (hairs/ } \\
100 \mu \mathrm{m}^{2} \text { ) }\end{array}$ \\
\hline Centris aenea & & $17.72 \pm 2.25$ & 11 \\
\hline Centris tarsata & & $15.5 \pm 1.36$ & 13 \\
\hline Centris analis & & $18.46 \pm 0.49$ & 12 \\
\hline Centris labrosa & & $19.2 \pm 1.0$ & 12 \\
\hline Centris violacea & & $21.06 \pm 0.71$ & 12 \\
\hline Centris fuscata & & $21.5 \pm 2.17$ & 17 \\
\hline Epicharis flava & & $24.25 \pm 4$ & 12 \\
\hline Epicharis rustica & & $16.29 \pm 1.26$ & 14 \\
\hline Epicharis bicolor & & $23.64 \pm 2.29$ & 13 \\
\hline Epicharis analis & & $17.7 \pm 0.90$ & 17 \\
\hline Epicharis schrottkyi & & $11.29 \pm 1.69$ & 16 \\
\hline $\begin{array}{l}\text { Exomalopsis } \\
\text { auropilosa }\end{array}$ & & nd & 8 \\
\hline $\begin{array}{l}\text { Exomalopsis } \\
\text { fulvofasciata }\end{array}$ & & nd & 7 \\
\hline $\begin{array}{l}\text { Melissoptila } \\
\text { richardiae }\end{array}$ & & $14.8 \pm 1.64$ & 3 \\
\hline Thygater analis & & $21.15 \pm 1.14$ & 14 \\
\hline Thygater palliventris & & $20.55 \pm 0.86$ & 12 \\
\hline $\begin{array}{l}\text { Melitoma } \\
\text { segmentaria }\end{array}$ & & nd & 9 \\
\hline Mesocheira bicolor & & $23.4 \pm 3.78$ & 14 \\
\hline $\begin{array}{l}\text { Arhysoceble } \\
\text { xanthopoda }\end{array}$ & & $21.73 \pm 4.25$ & 7 \\
\hline Xylocopa frontalis & $\begin{array}{l}\text { Long hair } \\
\text { Barbed hair }\end{array}$ & $\begin{array}{r}76.77 \pm 5.78 \\
4.34 \pm 1.52\end{array}$ & $\begin{array}{r}6 \\
\text { nd }\end{array}$ \\
\hline Xylocopa subcyanea & $\begin{array}{l}\text { Long hair } \\
\text { Barbed hair }\end{array}$ & $\begin{array}{c}78.40 \pm 3.60 \\
5.75 \pm 0.7\end{array}$ & $\begin{array}{r}6 \\
\text { nd }\end{array}$ \\
\hline Oxaea flavescens & $\begin{array}{l}\text { Long hair } \\
\text { Short hair }\end{array}$ & $\begin{array}{l}41.51 \pm 6.02 \\
12.01 \pm 1.21\end{array}$ & $\begin{array}{r}5 \\
\text { nd }\end{array}$ \\
\hline Anthidum latum & & $29.80 \pm 7.13$ & 7 \\
\hline $\begin{array}{l}\text { Anthiduum } \\
\text { manicatum }\end{array}$ & & $13.8 \pm 1.6$ & 12 \\
\hline Megachile giraffa & & $20.69 \pm 2.46$ & 7 \\
\hline $\begin{array}{l}\text { Megachile } \\
\text { aureiventris }\end{array}$ & & $19.43 \pm 3.41$ & 8 \\
\hline Megachile paulistana & & $29.45 \pm 1.46$ & 7 \\
\hline Ptiloglossa $\mathrm{sp}$ & & $18.64 \pm 1.86$ & 5 \\
\hline Psenulus sp. & & $29.84 \pm 5.08$ & 15 \\
\hline Polybia paulista & & nd & nd \\
\hline Polistes versicolor & & nd & nd \\
\hline
\end{tabular}

nd $=$ not determined.

and D-1. A trichotomy is found in node 5 that includes Arhysoceble, Melitoma and Exomalopsis. Node 9, which includes Xylocopinae, Colletidae and Melissoptila, is based on low hair density (character C-2), whereas Xylocopinae monophyly is supported by a strong autapomorphy (barbed hairs). Node 11 (Megachilidae) is strongly supported by character state A-3. The same 

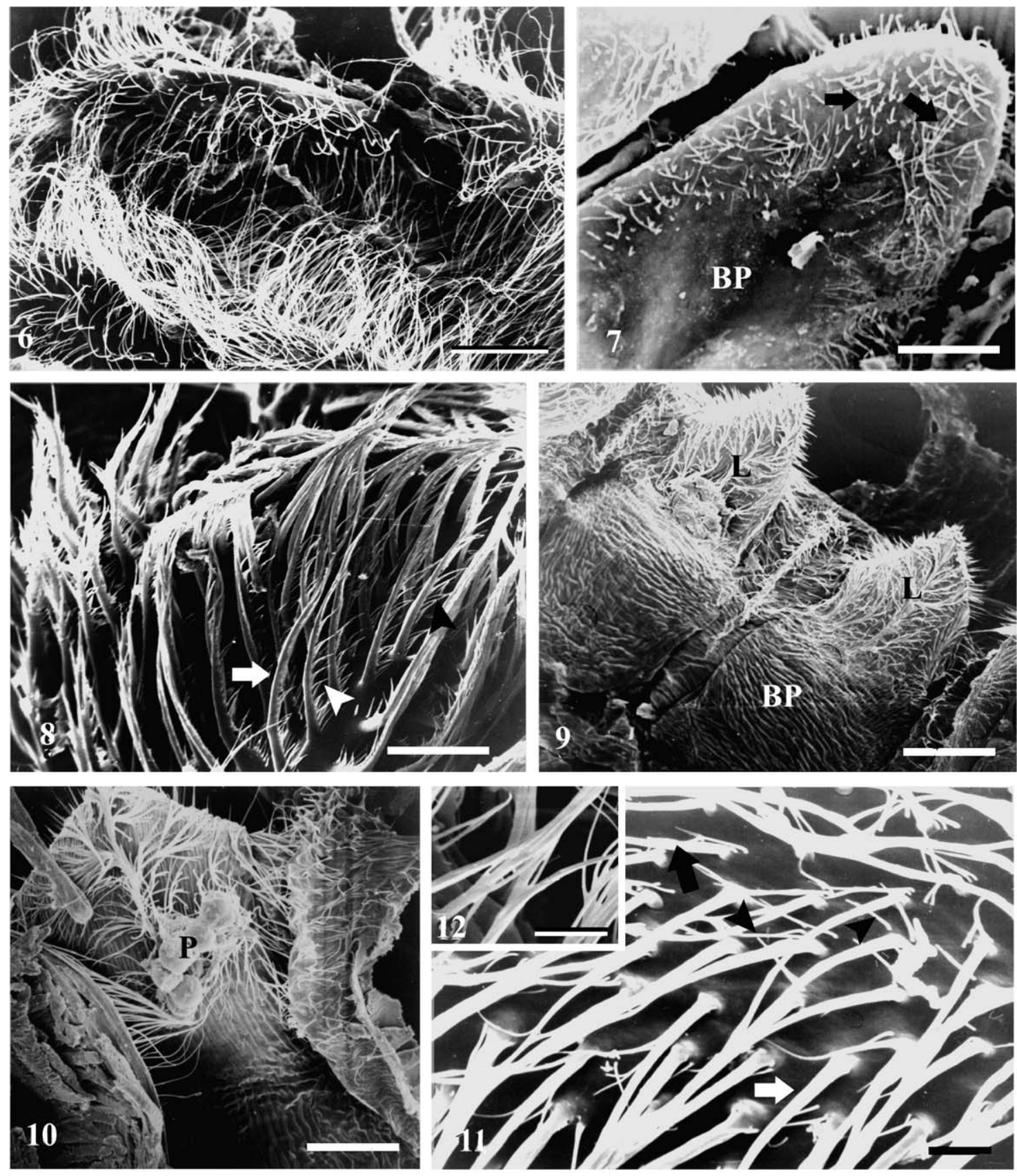

Figs. 6-12. Scanning electron micrographs of proventriculus structures. 6. Long, thread-shaped and densely packed proventricular hairs in Exomalopsis aureopilosa (Exomalopsini); scale bar $=30 \mu \mathrm{m}$. 7. Proventricular bulb in Melissoptila richardiae (Eucerini), showing short and scarce hairs (arrows); $\mathrm{BP}=$ basal plate; scale bar $=50 \mu \mathrm{m}$. 8. Proventricular hairs in Xylocopa (Neoxylocopa) frontalis (Xylocopinae), with hairs (arrow) that are barbed (arrowheads); scale bar $=20 \mu \mathrm{m}$. 9. Inner view of proventricular folds in Megachile (Leptorachis) aureiventris (Megachilidae), showing widened basal plate (BP); L = movable lips; scale bar $=100 \mu \mathrm{m}$. 10 . Proventricular lips in Megachile (Holcomegachile) giraffa, showing thread-shaped hairs of low density; $\mathrm{P}=$ pollen grain; scale bar $=50 \mu \mathrm{m}$. 11. Long (arrow) and short (arrowheads) hairs on inner surface of proventriculus in Oxaea flavescens; scale bar $=10 \mu \mathrm{m}$. 12. Hairs with cylindrical base and long branches on outer surface of proventricular bulb in Oxaea flavescens (Andrenidae); scale bar $=10 \mu \mathrm{m}$.

applies to Oxaea, which has an autapomorphy in character state E-1.

Most of the remaining nodes are weakly supported, because the same states also appear elsewhere in the tree.

\section{Discussion}

The observed differences in hair length do not correlate with differences in body size, but may suggest 

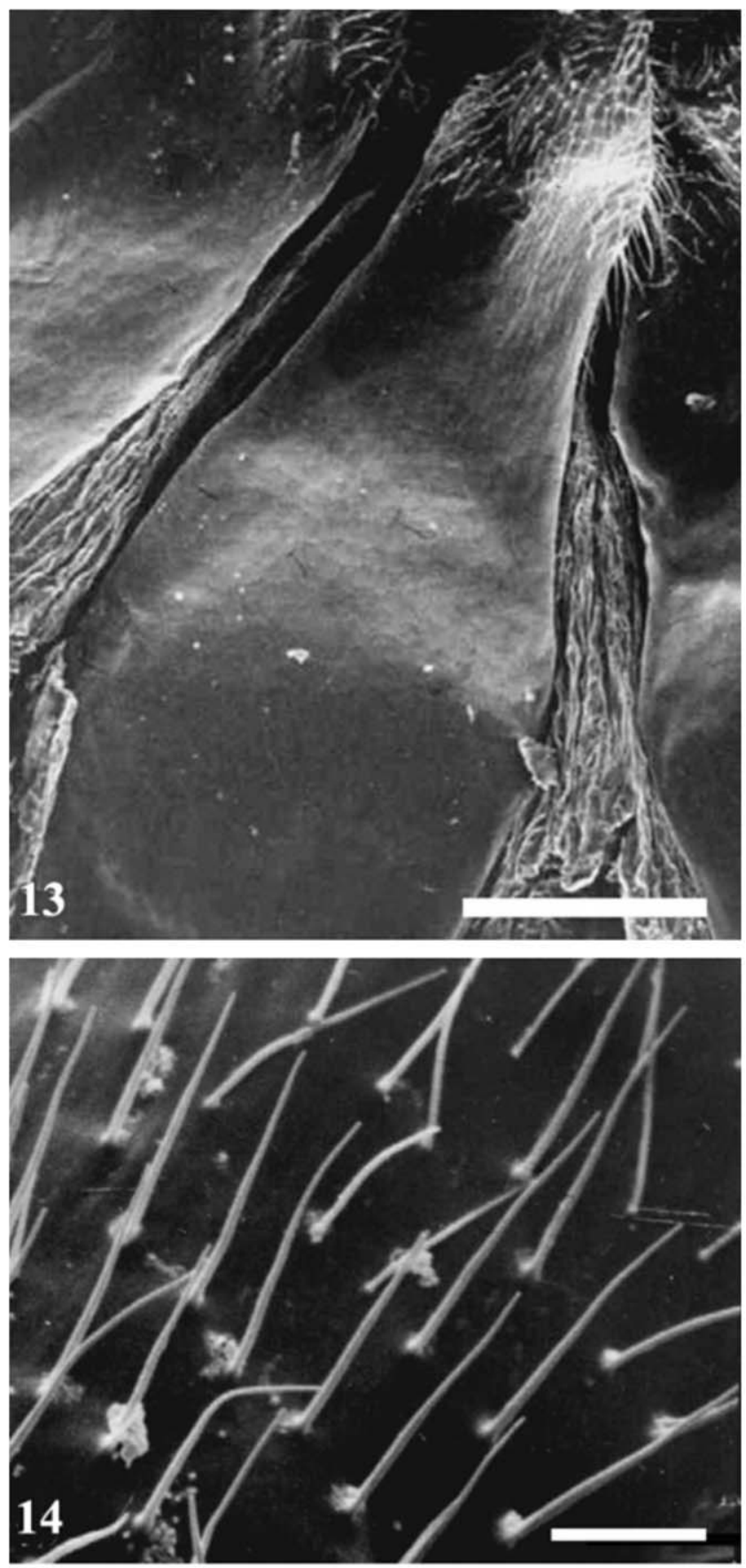

Figs. 13-14. Scanning electron micrographs of proventriculus structures. 13. Proventricular bulb in Ptiloglossa sp., showing basally enlarged folds that become triangular towards their apices; scale bars $=100 \mu \mathrm{m}$. 14. Spine-like cuticular projections on proventriculus in Ptiloglossa sp.; scale bar $=10 \mu \mathrm{m}$.

that species with low proventricular hair density have longer hairs, which is supported by this characteristic in Xylocopa, Oxaea, Exomalopsis and Melitoma, although not in Melissoptila. As the function of the hairs is to transfer solid particles of food (pollen grains) from the crop to the midgut (Peng and Marston, 1986), species with few proventricular hairs have this functional activity enhanced by long hairs.
Presence of a proventricular bulb formed by four folds of the wall corroborates the hypothesis of Serrão (2000) that this structural organization of the proventriculus is a symplesiomorphy for bees, because similar proventriculi were found in other bee groups and sphecid wasps (Serrão and Cruz-Landim, 1995; Serrão, 2000), ants (Caetano, 1984), and Polistinae wasps (von Zuben and Caetano, 1994). 
Table 3. Matrix of proventriculus character states (see Appendix A).

\begin{tabular}{|c|c|c|c|c|c|c|c|c|c|}
\hline \multirow[t]{2}{*}{ Family } & \multirow[t]{2}{*}{ Subfamily } & \multirow[t]{2}{*}{ Tribe } & \multirow[t]{2}{*}{ Species } & \multicolumn{5}{|c|}{ Character } & \\
\hline & & & & A & B & $\mathrm{C}$ & $\mathrm{D}$ & $\mathrm{E}$ & \\
\hline \multirow{21}{*}{ Apidae } & \multirow[t]{19}{*}{ Apinae } & \multirow[t]{11}{*}{ Centridini } & Centris aenea & 1 & 0 & 0 & 0 & 0 & \\
\hline & & & Centris tarsata & 1 & 0 & 0 & 0 & 0 & \\
\hline & & & Centris analis & 1 & 0 & 0 & 0 & 0 & \\
\hline & & & Centris labrosa & 1 & 0 & 0 & 0 & 0 & \\
\hline & & & Centris violacea & 1 & 0 & 0 & 0 & 0 & \\
\hline & & & Centris fuscata & 1 & 0 & 0 & 0 & 0 & \\
\hline & & & Epicharis flava & 1 & 0 & 0 & 0 & 0 & \\
\hline & & & Epicharis rustica & 1 & 0 & 0 & 0 & 0 & \\
\hline & & & Epicharis bicolor & 1 & 0 & 0 & 0 & 0 & \\
\hline & & & Epicharis analis & 1 & 0 & 0 & 0 & 0 & \\
\hline & & & Epicharis schrottkyi & 1 & 0 & 0 & 0 & 0 & \\
\hline & & \multirow[t]{2}{*}{ Exomalopsini } & Exomalopsis auropilosa & 1 & 1 & 1 & 0 & 0 & \\
\hline & & & Exomalopsis fulvofasciata & 1 & 1 & 1 & 0 & 0 & \\
\hline & & \multirow[t]{3}{*}{ Eucerini } & Melissoptila richardiae & 1 & 3 & 2 & 0 & 0 & \\
\hline & & & Thygater analis & 1 & 0 & 0 & 0 & 0 & \\
\hline & & & Thygater palliventris & 1 & 0 & 0 & 0 & 0 & \\
\hline & & Emphoprini & Melitoma segmentaria & 1 & 1 & 1 & 0 & 0 & \\
\hline & & Ericrocidini & Mesocheira bicolor & 1 & 0 & 0 & 0 & 0 & \\
\hline & & Tapinotaspidini & Arhysoceble xanthopoda & 1 & 1 & 1 & 0 & 0 & \\
\hline & \multirow[t]{8}{*}{ Xylocopinae } & & Xylocopa frontalis & 1 & 2 & 2 & 0 & 0 & \\
\hline & & & Xylocopa subcyanea & 1 & 2 & 2 & 0 & 0 & \\
\hline \multirow[t]{6}{*}{ Andrenidae } & & & Oxaea flavescens & 1 & 1 & 2 & 1 & 1 & \\
\hline & & \multirow[t]{2}{*}{ Megachilidae Anthidini } & Anthidium latum & 3 & 1 & 1 & 1 & 0 & \\
\hline & & & Anthidium manicatum & 3 & 1 & 1 & 1 & 0 & \\
\hline & & \multirow[t]{7}{*}{ Megachilini } & Megachile giraffa & 3 & 1 & 1 & 1 & 0 & \\
\hline & & & Megachile aureiventris & 3 & 1 & 1 & 1 & 0 & \\
\hline & & & Megachile paulistana & 3 & 1 & 1 & 1 & 0 & \\
\hline Colletidae & & & Ptiloglossa sp. & 2 & 3 & 2 & 0 & 0 & \\
\hline Sphecidae & & & Psenulus sp. & 0 & 0 & 0 & 0 & 0 & \\
\hline \multirow[t]{2}{*}{ Vespidae } & & & Polybia paulista & 0 & 0 & 0 & $?$ & 0 & \\
\hline & & & Polistes versicolor & 0 & 0 & 0 & $?$ & 0 & \\
\hline
\end{tabular}

The proventricular hairs forming plates with numerous spine-like tips were also found in Bombini, Euglossini, Sphecidae and Halictidae (Serrão, 2000), and in Polistinae wasps (von Zuben and Caetano, 1994). In relation to the other character states in the proventricular hairs, thread shape constitutes a synapomorphy for Exomalopsini, Tapinotaspidini and Emphorini. On the other hand, a very low density of short hairs may be considered an apomorphy for Melissoptila, which disagrees with their inclusion in Eucerini, because the two Thygater species have hairs similar to those found in Centridini and Ericrocidini. Thus, I consider that the proventricular hairs are a multi-state character, with organization in plates with spine-like projections being the plesiomorphic condition, because this is the hair condition found in the outgroups, whereas the others states are derived.

Barbed hairs also have been observed in Xylocopa coerulescens (see Tosi, 1895), and this condition can be considered an apomorphy for Xylocopa, corroborating the subfamily status of Xylocopinae as proposed by Roig-Alsina and Michener (1993).

Presence of two types of hairs found in the proventricular movable lips of $O$. flavescens is a condition considered an apomorphy for Andrenidae.

Serrão (2000) suggests that a columnar fold is a symplesiomorphic condition for bees, thus the widened basal plate is an apomorphic condition for Megachilidae, because it is present in both Anthidini and Megachilini. The pattern of proventricular folds in Ptiloglossa suggests an apomorphy for the genus.

A phylogeny based solely on proventriculus characteristics results in a tree with some differences from the phylogeny based on conventional morphological characters (Roig-Alsina and Michener, 1993; Alexander and Michener, 1995). However, some considerations may be hypothesized. Eucerini is not a monophyletic clade, because Melissoptila cannot be included together with 


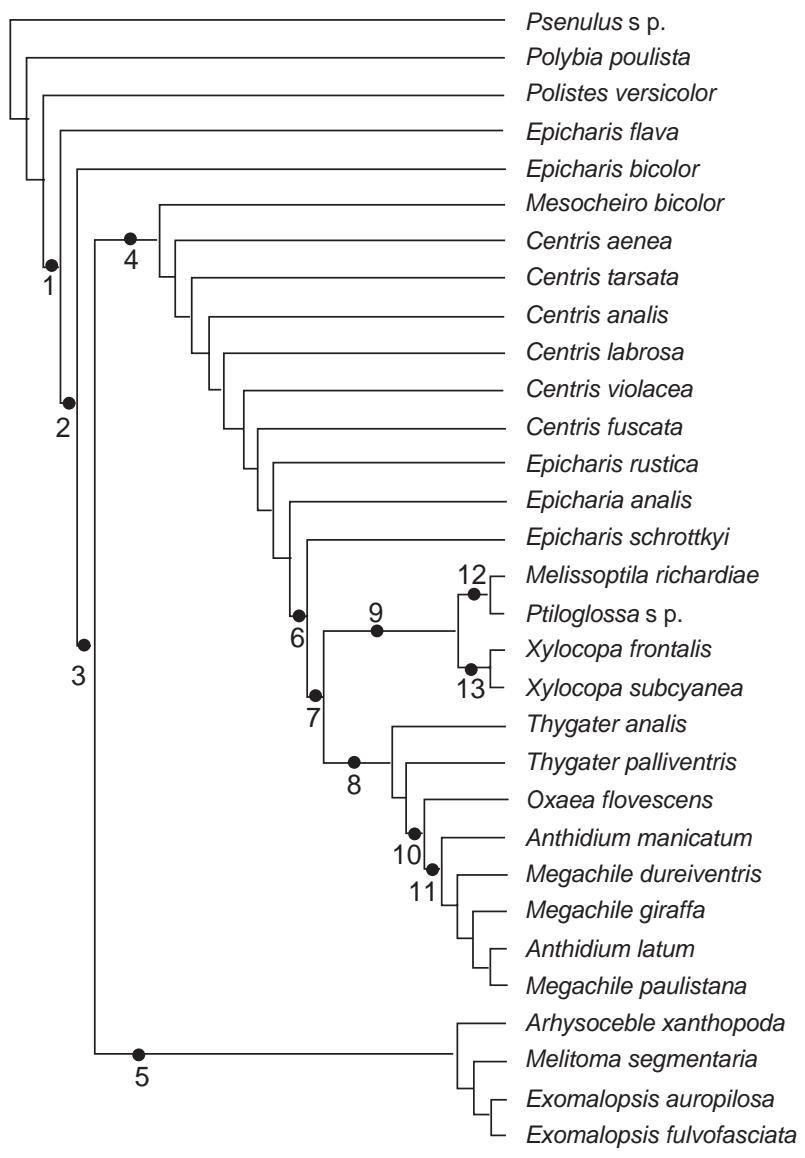

Fig. 15. Strict consensus of 13 trees based on proventricular characters (star-decomposition search option; $\mathrm{TL}=13$, $\mathrm{CI}=0.77, \mathrm{RI}=0.91)$.

Thygater species. Ericrocidini, Tapinotaspidini, Exomalopsini and Emphorini constitute a related group. Moreover, character A-1 (long columnar proventricular fold) is widely distributed, and characters D-1 (spinelike hairs) and C-1 (medium hair density) appear in Megachilidae, thus this group would have little support. On the other hand, this clade agrees with cladogram $2 \mathrm{~b}$ of Roig-Alsina and Michener (1993). Megachilidae is a monophyletic clade, which has been well known. For Andrenidae and Colletidae only one species each was analyzed, thus further phylogenetic considerations are impossible here.

In the cladogram (Fig. 15), the paraphyletic Sphecidae (Alexander, 1992) is sister group to bees + wasps, making Apoidea paraphyletic. However, the present work professes itself with matters inside Apoidea, and the number of characters and species for Vespidae and Sphecidae do not permit conclusions on major relationships, because they are used only for the determination of character polarity.

The use of quantitatively variable characters in phylogenetic analysis has been criticized, because coding quantitative characters into states may introduce artificial distinctions in cladistic analyses (Pimentel and Riggins, 1987; Farris, 1990). On the other hand, quantitative characters should be used when there is no overlap among their character states, and the arguments against their use are not supported by systematic theory (Zelditch et al., 1995; Swiderski et al., 1998). In the analysis presented here, morphometric data are useful because they represent autapomorphies that strongly support the Xylocopa and Oxaea clades.

As phylogenetic analyses should be made using the greatest possible number of characters, my contribution is to show that the proventricular characteristics can provide insights into the relationships of bees.

\section{Acknowledgements}

This work was supported by the Brazilian research agencies $\mathrm{CNPq}$ and FAPEMIG. I thank Dr. F.A. Silveira (UFMG) and Dr. L.A.O. Campos (UFV) for help with species identifications, and Dr. M.L. Triques (UFMG) for productive criticism. The author is a staff member of UFV and research fellow of CNPq.

\section{Appendix A}

\section{Annotated list of proventriculus characters}

A. Shape of proventricular fold: (0) short columnar; (1) long columnar; (2) triangular; (3) widened.

B. Shape of hairs: (0) plate-shaped with spine-like projections; (1) thread-shaped; (2) barbed; (3) spine-like.

C. Hair density: (0) high; (1) medium; (2) low.

D. Shapes of hairs on external apex and movable lips: (0) all hairs similar; (1) various hair shapes.

E. Shapes of hairs on movable lips: (0) all hairs similar; (1) various hair shapes.

F. Range of hair length in $\mu \mathrm{m}$ : (0) 24.7-29.9; (1) 12.2-23.8; (2) 35.5-45.5; (3) 71.0-81.0.

\section{References}

Alexander, B.A., 1992. An exploratory analysis of cladistic relationships within the superfamily Apoidea, with special reference to sphecid wasps (Hymenoptera). J. Hym. Res. 1, 25-61.

Alexander, B.A., Michener, C.D., 1995. Phylogenetic studies of the families of short-tongued bees (Hymenoptera: Apoidea). Univ. Kansas Sci. Bull. 55, 377-424.

Bailey, L., 1952. The action of the proventriculus of the worker honeybee, Apis mellifera L. J. Exp. Biol. 29, 310-317.

Bilinski, S.M., Büning, B., Simiczyjew, B., 1998. The ovaries of Mecoptera: basic similarities and one exception to the rule. Folia Histochem. Cytobiol. 36, 189-195. 
Bitsch, C., Bitsch, J., 1998. Internal anatomy and phylogenetic relationships among apterygote insect clades (Hexapoda). Ann. Soc. Ent. France 34, 339-363.

Buschbeck, E.K., 2000. Neurobiological constraints and fly systematics: how different types of neural characters can contribute to a higher level dipteran phylogeny. Evolution 54, 888-898.

Caetano, F.H., 1984. Morfologia comparada do trato digestivo de formigas da subfamília Myrmicinae (Hymenoptera, Formicidae). Pap. Avul. Zool. 35, 257-305.

Caetano, F.H., 1988. Anatomia, histologia e histoquímica do sistema digestivo e excretor de operárias de formigas (Hymenoptera, Formicidae). Naturalia 13, 129-174.

Cameron, S., 1991. A new tribal phylogeny of the Apidae inferred from mitochondrial DNA sequences. In: Smith, D.R. (Ed.), Diversity in the Genus Apis. Western Press, Boulder, CO, pp. 71-87.

Cane, J.M., 1987. Estimation of bee size using intertegular span. J. Kansas Ent. Soc. 60, 147.

Chapman, R.F., 1998. The Insects. Structure and Function. American Elsevier, New York.

Costa, M.A., Del Lama, M.A., Melo, G.A.R., Sheppard, W.S., 2003. Molecular phylogeny of the stingless bees (Apidae, Apinae, Meliponini) inferrred from mitochondrial 16S rDNA sequences. Apidologie 34, 73-84.

Cruz-Landim, C., Rodrigues, L., 1967. Comparative anatomy and histology of the alimentary canal of adult Apinae. J. Apic. Res. 6, 17-28.

Drumond, P.M., Zucchi, R., Oldroyd, B.P., 2000. Description of the cell provisioning and oviposition process of seven species of Pebleia Schwarz (Apidae, Meliponini), with notes on their phylogeny and taxonomy. Insect. Soc. 47, 99-112.

Ehmer, B., Hoy, R.R., 2000. Mushroom bodies of vespid wasps. J. Comp. Neur. 416, 93-100.

Engel, M.S., 2000. Classification of the bee tribe Augochlorini (Hymenoptera: Halictidae). Bull. Am. Mus. Nat. Hist. 250, $1-89$.

Farris, J.S., 1990. Phenetics in camouflage. Cladistics 6, 91-100.

Gibbs, D.G., 1967. The proventriculus of some trichopterous larvae. J. Zool. Lond. 152, 245-256.

Klass, K.D., 1998. The proventriculus of the Dicondyla, with comments on evolution and phylogeny in Dictyoptera and Odonata (Insecta). Zool. Anz. 237, 15-42.

Kubrakiewicz, J., Jedrzejowska, I., Bilinski, S.M., 1998. Neuropteroidea - different ovary structure in related groups. Folia Histochem. Cytobiol. 36, 179-187.

Lebrun, D., 1985. Structures digestives et régimes alimentaires des termites. Actes Coll. Ins. Soc. 2, 43-44.

Lebrun, D., Lequet, A., 1985. Relations entre le régimes alimentaires et la structure du gésier des termites. Bull. Soc. Sci. Nat. Ouest France, N. S. 7, 126-139.

Maddison, W.P.O., Donoghue, M.J., Maddison, D.R., 1984. Outgroup analysis and parsimony. Syst. Zool. 33, 88-103.
Nation, J.L., 1983. A new method using hexamethyldisilazane for preparation of soft insect tissues for scanning electron microscopy. Stain Tech. 58, 347-351.

Nixon, K.C., Carpenter, J.M., 1993. On outgroups. Cladistics 9, 413-426.

Peixoto, E.B.M.I., Serrão, J.E., 2001. A comparative study of the cardia and cardiac valves in corbiculate bees (Hymenoptera, Apinae). Sociobiology 37, 707-721.

Peng, Y.S., Marston, J.R., 1986. Filtering mechanism of the honeybee proventriculus. Physiol. Entomol. 11, 433-439.

Pimentel, R.A., Riggins, R., 1987. The nature of cladistic data. Cladistics 3, 201-209.

Roig-Alsina, A., Michener, C.D., 1993. Studies of the phylogeny and classification of long-tongued bees (Hymenoptera, Apoidea). Univ. Kansas Sci. Bull. 55, 123-162.

Serrão, J.E., 2000. A comparative study of the proventricular structure in corbiculate Apinae (Hymenoptera, Apidae). Micron 32, 379-386.

Serrão, J.E., Cruz-Landim, C., 1995. Scanning electronic microscopy of the proventriculus in stingless bees (Apidae: Meliponinae) with a comparison of necrophagous and feeding pollen workers. Naturalia 20, 207-212.

Sheppard, W.S., McPherson, B.A., 1991. Ribosomal DNA diversity in Apidae. In: Smith, D.R. (Ed.), Diversity in the Genus Apis. Western Press, Boulder, CO, pp. 87-102.

Silveira, F.A., Melo, G.A.R., Almeida, E.A.B., 2002. Abelhas Brasileiras: Sistemática e Identificação. Fernando A. Silveira, Belo Horizonte.

Smith, F., 1853. Catalogue of Hymenopterous Insects in the Collection of the British Museum. Part I. British Museum, London.

Snodgrass, R.E., 1956. Anatomy of the Honeybee. Comstock Book Company, New York.

Strausfeld, N.J., 1998. Crustacean-insect relationships: the use of brain characters to derive phylogeny amongst segmented invertebrates. Brain Behav. Evol. 52, 186-206.

Swiderski, D.L., Zelditch, M.L., Fink, W., 1998. Why morphometics is not special: coding quantitative data for phylogenetic analysis. Syst. Biol. 47, 508-519.

Swofford, D.L., 1998. PAUP*. Phylogenetic Analysis Using Parsimony (*and Others Methods), version 4. Sinauer Associates, Sunderland, Massachusetts.

Terra, W.R., Ferreira, C., 1994. Insect digestive enzymes: properties, compartmentalization and function. Comp. Bioch. Physiol. 109B, 1-62.

Tosi, A., 1895. Osservazioni sulla valvola del cardias in varii generi della famiglia delle apidi. Ric. Lab. Anat. Norm. R. Univ. Roma. 5, 6-26.

Watrous, L.E., Wheeler, D., 1981. The out-group comparison method of character analysis. Syst. Zool. 30, 1-11.

Zelditch, M.L., Fink, W., Swiderski, D.L., 1995. Morphometrics, homology and phylogenetics: quantified characters as synapomorphies. Syst. Biol. 44, 179-189.

von Zuben, C.J., Caetano, F.H., 1994. Ultramorfologia do proventrículo de Polybia paulista (Ihering, 1896) e Polistes versicolor (Oliver, 1791) (Hymenoptera, Vespidae). Naturalia 19, 45-54. 